\title{
Kombinasi Ekstrak Batang Talikuning dan Artemisin sebagai Obat Antimalaria terhadap Plasmodium berghei
}

\section{Combination of Anamirta cocculus Stem Extract and Artemisin as an Antimalaria Agent against Plasmodium berghei}

\author{
Roihatul Muti'ah ${ }^{1}$, Loeki Enggar $F^{2}$, Sri Winarsih ${ }^{3}$, Soemarko ${ }^{3}$, Dorta Simamora ${ }^{4}$ \\ ${ }^{1}$ Fakultas Saintek Universitas Islam Negeri Maulana Malik Ibrahim Malang \\ ${ }^{2}$ Laboratorium Parasitologi Fakultas Kedokteran Universitas Brawijaya Malang \\ ${ }^{3}$ Laboratorium Mikrobiologi Fakultas Kedokteran Universitas Brawijaya Malang \\ ${ }^{4}$ Universitas Satya Wyata Mandala Nabire
}

\begin{abstract}
ABSTRAK
Malaria, penyakit menular dengan tingkat kematian yang tinggi sekarang menghadapi penurunan kemanjuran obat obat pilihan pertama yaitu kombinasi artemisin dan amodiaquine. Talikuning (Anamirta cocculus), adalah jamu tradisional yang secara empiris digunakan sebagai antimalaria di Papua telah disarankan untuk meningkatkan efektivitas kombinasi obat antimalaria. Talikuning batang dan akar mengandung alkaloid kuartener yang dianggap memiliki aktivitas fisiologis sebagai antimalaria. Penelitian ini bertujuan untuk memahami efek antimalaria dari ekstrak batang talikuning dan kombinasinya dengan artemisin pada derajat parasitemia mencit terinfeksi Plasmodium berghei. Peritoneal tikus yang terinfeksi dengan Plasmodium berghei ANKA 106 dan dibagi menjadi 11 kelompok perlakuan, kontrol negatif, kontrol positif; artemisin dosis 0,04 mg / g BB; talikuning dosis: 0,001 mg / g BB; 0,01 mg / g BB; 0, $1 \mathrm{mg} / \mathrm{g}$ BB, dan $1 \mathrm{mg} / \mathrm{g}$ BB. Dan kombinasi artemisin talikuning dosis: 0,001 mg / g BB; 0,01 mg / g BB, 0,1 mg / g BB; and1 mg / g BB. Pengobatan dimulai pada hari 0 di mana derajat parasitemia mencapai 5-15\% dan dilanjutkan selama 7 hari, observasi parasitemia dilakukan pada hari 3, 5 dan 7 hari. Hasil penelitian menunjukkan ekstrak talikuning induk bisa menghambat pertumbuhan Plasmodium berghei secara signifikan $(p<0,05)$ terhadap kontrol dengan ED50 dari $0,043 \mathrm{mg} / \mathrm{g}$ BB tikus yang setara dengan 4,7 mg / kg BB manusia. Namun demikian, kombinasi dosis-talikuning artemisin tidak menunjukkan perbedaan yang signifikan dibandingkan dengan pengobatan monoterapi artemisin $(p>0,05)$ baik pada hari 3, 5 dan 7 hari pasca terapi. Hal ini menunjukkan bahwa pemberian kombinasi-talikuning artemisin tidak berbeda dari penyediaan artemisin monoterapi.
\end{abstract}

Kata Kunci : Antimalaria, artemisin, derajat parasitemia, Plasmodium berghei, talikuning

\begin{abstract}
Malaria, an infectious disease with high mortality rate is now encounter efficacy decrease of its firstline drug, combination of artemisin and amodiaquine. Talikuning (Anamirta cocculus), is a traditional herbal medicine that empirically used as an antimalarial in Papua with active ingredient quartener alkaloids. This study aimed to identify antimalarial effect of talikuning stem extract and its combination with artemisin on the degree of parasitemia of Plasmodium berghei infected mice. Mice were peritoneal infected with 106 Plasmodium berghei ANKA and divided into 11 treatment groups, negative control; positive control; artemisin of dose $0,04 \mathrm{mg} / \mathrm{gBB}$; talikuning of dose: $0,001 \mathrm{mg} / \mathrm{gBB} ; 0,01 \mathrm{mg} / \mathrm{gBB} ; 0,1 \mathrm{mg} / \mathrm{gBB} ; \mathrm{and}$ $1 \mathrm{mg} / \mathrm{gBB}$ and combination of artemisin and talikuning combination in four dose: 0,001 mg/gBB; 0,01 mg/gBB; 0,1 $\mathrm{mg} / \mathrm{gBB}$; and $1 \mathrm{mg} / \mathrm{gBB}$. Treatment were started on day 0 where the degree of parasitemia reached $5-15 \%$ and continued for 7 days, parasitemia observation carried out on day 3, day 5 and day 7 . The results showed talikuning stem extract could inhibit the growth of Plasmodium berghei significantly $(p<0.05)$ against control with ED50 of 0,043 $\mathrm{mg} / \mathrm{g}$ BW of mice that equal to $4.7 \mathrm{mg} / \mathrm{kg} B B$ of human. However, the combination dose-talikuning artemisin showed no significant difference compared to artemisin monotherapy treatment ( $p>0.05$ ) either on day 3 , day 5 and day 7 post-therapy. This indicates that administration of combination-talikuning artemisin did not differ from the provision of monotherapy artemisin.
\end{abstract}

Keywords: Antimalarial, artemisin, degree of parasitemia, Plasmodium berghei, talikuning

Jurnal Kedokteran Brawijaya, Vol. 26, No. 1, Februari 2010; Korespondensi: Roihatul Muti'ah. Fakultas Saintek Universitas Islam Malang Maulana Malik Ibrahim Malang, Jl. Gajayana No. 50 Malang Tel. (0341) 551354 Email : mroihatul@yahoo.com 


\section{PENDAHULUAN}

Malaria adalah penyakit yang disebabkan oleh infeksi parasit Plasmodium pada sel darah merah melalui gigitan nyamuk Anopheles betina. Penyakit ini menjadi penyebab kematian ke-tiga pada kasus penyakit infeksi. Setiap tahun 350-500 juta penduduk dunia menderita malaria, dan lebih dari satu juta orang meninggal dunia karena penyakit ini (1). Di Indonesia, terutama Indonesia bagian tengah dan timur penyakit ini termasuk dalam 10 penyakit terbesar yang banyak menyerang masyarakat di pedesaan (2).

Penyebab utama tingginya angka kejadian penyakit malaria adalah karena semakin meningkatnya angka kejadian resistensi Plasmodium falciparum terhadap obat antimalaria (3). Peningkatan kasus resisten terhadap obat standar yaitu khlorokuin (CQ) dan sulfadoksinpirimetamin (SP) telah terjadi di hampir seluruh propinsi di Indonesia. Di beberapa propinsi angka kejadian resistensi tersebut sudah melebihi $25 \%$, sehingga obatobat lama seperti klorokuin, sulfadoksin-pirimetamin sudah tidak dapat dipertahankan sebagai obat utama (4). Mekanisme terjadinya resistensi adalah karena mutasi genetik yang terjadi secara alami pada parasit malaria yang memberikan keuntungan bagi parasit agar tetap bertahan hidup (5). Obat yang memiliki waktu paruh panjang lebih mudah menyebabkan resistensi.

Dengan makin meningkatnya angka kejadian resistensi tersebut, saat ini obat pilihan yang digunakan untuk terapi malaria adalah Artemisin yang diambil dari tanaman Artemisia annua. Artemisin merupakan antimalaria yang mempunyai potensi yang sangat kuat. la dapat membunuh parasit di peredaran darah tepi sampai 95\% dalam waktu 24 jam, tetapi tidak dapat membunuh hipnozoit, dan hanya sedikit berpengaruh pada gametosit (6). Selain itu artemisin mempunyai waktu paruh yang singkat sehingga sering timbul rekrudesensi setelah terapi (3). Akhir-akhir ini juga dilaporkan bahwa parasit Plasmodium juga mulai resisten terhadap Artemisin. Uji sensitifitas dehydroartemisin terhadap Plasmodium falciparum secara in vitro menunjukkan adanya peningkatan Ic50 (4). Oleh karena itu untuk mencegah timbulnya resistensi terhadap artemisin WHO menganjurkan agar penggunaan Artemisin tidak diberikan secara tunggal, melainkan dikombinasi dengan obat antimalaria atau obat supportif lainnya (7).

Plasmodium berghei merupakan salah satu spesies malaria yang menyerang mamalia selain manusia, atau salah satu dari empat spesies yang menyerang rodensia di Afrika Barat. Plasmodium berghei merupakan model ideal untuk penelitian parasit malaria dibandingkan tiga spesies parasit rodensia di Afrika Barat. Plasmodium berghei merupakan model ideal untuk penelitian parasit malaria dibandingkan tiga spesies parasit rodensia yang lain, karena telah tersedianya teknologi kultivasi in vitro dan dapat dilakukan dalam skala besar, adanya data tentang pemetaan dan struktur gen, metode untuk memodifikasi parasit secara genetis, dan klon-klon yang khas serta galur-galur mutan yang dimodifikasi secara genetis (8).

Menurut WHO diperkirakan $80 \%$ penduduk negara berkembang menggunakan tanaman obat di lingkungannya untuk mengatasi masalah kesehatan, salah satunya adalah untuk mengatasi penyakit malaria (9). Tanaman obat menjadi salah satu pilihan terapi karena efek sampingnya lebih rendah, murah dan mudah di dapat. Oleh karena itu saat ini para ilmuwan melakukan berbagai penelitian untuk menemukan senyawa-senyawa yang berefek antimalaria terutama yang terkandung pada tanaman obat yang telah banyak dipakai masyarakat tetapi masih belum ada pembuktian secara ilmiah.

Tanaman talikuning (Anamirta cocculus) merupakan tanaman yang tumbuh di Asia-tenggara (10). Secara empiris batang talikuning telah digunakan oleh penduduk Papua untuk pengobatan terhadap malaria dan penurun panas. Penelitian yang dilakukan di Indonesia tentang isolasi dan identifikasi senyawa kimia pada tanaman Anamirta cocculus memberikan hasil adanya senyawa alkaloid kuartener pada batang tanaman tersebut. Alkaloid kuartener tersebut adalah beriberine, palmatine, magnoflorine dan columbamine (11). Aktivitas antimalaria dari alkaloid kuartener ini diduga melalui penghambatan transport kolin pada biosintesis foosfatidilkolin untuk membentuk membran parasit baru, sehingga menyebabkan kegagalan terbentuknya parasit baru (12). Sejauh ini belum banyak laporan dan bukti ilmiah tentang efektivitas penggunaan tanaman talikuning ini untuk pengobatan malaria.

Berdasarkan fakta di atas maka dilakukan penelitian tentang aktivitas antimalaria dari ekstrak batang talikuning (Anamirta cocculus) pada hewan coba (mencit jantan galur balb/C) yang diinfeksi Plasmodium berghei. Selain itu juga dilakukan pengujian aktivitas antimalaria ekstrak batang talikuning dalam bentuk kombinasi dengan artemisin. Hasil penelitian ini diharapkan dapat memberi informasi tentang efek yang sinergis sehingga menghasilkan formula obat kombinasi baru yang mempunyai efek antimalaria lebih baik dari pada artemisin monoterapi.

\section{METODE}

Penelitian eksperimental murni ini dilakukan dengan menggunakan desain postest only control group design. Penelitian ini dilakukan di Laboratorium Farmakologi dan Laboratorium Parasitologi Fakultas Kedokteran Universitas Brawijaya Malang

Batang talikuning (Anamirta cocculus) diperoleh dari daerah Papua. Batang diserbuk kemudian diekstraksi menggunakan pelarut etanol $80 \%$ dengan metode maserasi (13).

\section{Hewan Coba}

Penelitian ini menggunakan hewan coba mencit albino galur Balb/c jantan, umur 8-12 minggu, berat 28-32, diambil dari Pusat Veterinaria Farma Surabaya (PUSVETMA) sejumlah 66 ekor. Mencit diberi pakan standar untuk hewan coba berupa comfeed dan minum ad libitum.

\section{Rancangan Percobaan}

Rancangan percobaan yang digunakan adalah rancangan acak lengkap. Mencit dibagi menjadi 11 kelompok perlakuan: (A) kelompok kontrol negatif yaitu kelompok perlakuan tanpa infeksi Plasmodium berghei dengan pemberian larutan cmc-Na 0,5\% (carboxy methyl cellulose $\mathrm{Na})$ 0,5 ml; (B) kelompok kontrol positif yaitu kelompok perlakuan yang diinfeksi 1×106 Plasmodium berghei dengan pemberian larutan $\mathrm{cmc} \mathrm{Na} 0,5 \% 0,5 \mathrm{ml}$; (C) kelompok artemisin yaitu kelompok perlakuan yang diinfeksi Plasmodium berghei dan diberi terapi artemisin 
dosis $0,04 \mathrm{mg} / \mathrm{g}$ BB sekali sehari secara per-oral kelompok talikuning (D-6) yaitu kelompok perlakuan yang diinfeksi Plasmodium berghei dan diberi terapi ekstrak batang talikuning dengan dosis $0,001 \mathrm{mg} / \mathrm{g}$ BB sekali sehari secara per-oral; kelompok kombinasi di bagi dalam 4 kelompok kombinasi $(\mathrm{H}-\mathrm{K})$ yaitu kelompok perlakuan yang diinfeksi Plasmodium berghei dan diberi terapi kombinasi artemisin dosis $0,04 \mathrm{mg} / \mathrm{g}$ BB dan ekstrak batang talikuning dengan dosis masing-masing $0,001 \mathrm{mg} / \mathrm{g} \mathrm{BB}$, $0,01 \mathrm{mg} / \mathrm{g}, 0,1 \mathrm{mg} / \mathrm{g}$ dan $1 \mathrm{mg} / \mathrm{g}$ BB sekali sehari secara per-oral;

Pengujian aktivitas antimalaria in vivo dilakukan dengan menggunakan metode Fitri modifikasi dari metode Peter (14). Terapi dilakukan ketika derajat parasitemia setelah infeksi mencapai infeksi selanjutnya dilakukan pengamatan parasitemia dilakukan pada hari ke- 0 , hari ke-3, hari ke-5 dan hari ke-7.

\section{Pembuatan Donor}

Eritrosit yang terinfeksi parasit di resuspensikan dalam $200 \mu l$ RPMI, kemudian diinjeksikan pada mencit secara intra-peritonial. Dilakukan pengamatan parasitemia. Ketika parasitemia mencit donor telah mencapai $2,5 \%$ maka digunakan untuk menginfeksi mencit yang lain (14).

\section{Inokulasi Parasit}

Inokulasi Plasmodium berghei dilakukan secara intera peritoneal sebanyak $1 \times 10^{6}$, jika derajat parasitemia mencit donor sebesar 2,5\% maka diambil darah sebesar $6,7 \mu \mathrm{l}$, kemudian di resuspensikan dalam $200 \mu \mathrm{l}$ RPMI. Setelah dilakukan infeksi selanjutnya dilakukan pengamatan parasitemia setiap hari hingga parasitemia mencapai 5-15\%. kemudian dilakukan terapi obat/ekstrak uji selama 7 hari (14).

\section{Pengukuran Derajat Parasitemia}

Mula-mula dibuat hapusan darah yang dilakukan dengan cara mengambil setetes darah dari ekor mencit dengan menggunting ekor mencit dan diteteskan pada kaca benda (6). Tetesan darah tersebut ditipiskan dengan menggunakan tepi kaca benda yang lain dan ditunggu sampai kering. Kemudian hasil hapusan ditetesi dengan methanol hingga merata dan ditunggu hingga kering. Selanjutnya dilakukan pewarnaan Giemsa dengan cara mencampurkan pewarna Giemsa dan Buffer Giemsa dengan perbandingan 1 : 9 dan diteteskan pada hapusan, ditunggu selama 20 menit, selanjutnya dibilas dengan air mengalir hingga tidak ada cat yang tersisa dan kemudian dikeringkan. Selanjutnya hapusan darah yang sudah dicat dilakukan pemeriksaan parasitemia di bawah mikroskop menggunakan pembesaran 1000x dengan menghitung jumlah eritrosit yang terinfeksi malaria dari 1000 eritrosit. Parasitemia merupakan jumlah eritrosit yang terinfeksi Plasmodium berghei dalam 1000 eritrosit.

Persentase penghambatan pertumbuhan parasit dihitung dengan rumus (6):

Inhibition $(\%)=100 \% \times$ (parasitemia of control positif - parasitemia of drug)

Parasitemia of control positif

Parasitemia kontrol positif diperoleh dari derajat parasitemia kelompok perlakuan yang diinfeksi Plasmodium berghei tanpa perlakuan terapi antimalaria.
Parasitemia of drug diperoleh dari derajat parasitemia kelompok perlakuan yang diinfeksi Plasmodium berghei dan diterapi obat antimalaria dan atau ekstrak tanaman percobaan.

\section{Analisis Data}

Untuk mengetahui perbedaan derajat parasitemia antara kelompok kontrol dengan perlakuan digunakan uji statistik one way ANOVA (analysis of varian). Hasil pengujian yang diperoleh digunakan untuk menggambarkan pengaruh pemberian perlakuan ekstrak batang Anamirta cocculus terhadap derajat parasitemia mencit bermakna atau tidak. Analisis Post Hoc dengan uji Tukey untuk mengetahui kelompok mana saja yang menunjukkan perbedaan yang signifikan.

Untuk mengetahui hubungan antara dosis ekstrak batang talikuning dengan efek penghambatan pertumbuhan Plasmodium berghei dilakukan uji korelasi bivariat. Sedangkan untuk menentukan harga ED50 di buat analisis probit dengan program SPSS. Harga ED50 ini menunjukkan besarnya dosis bahan uji yang dapat menghambat pertumbuhan 50\% Plasmodium berghei. Semakin kecil harga ED50 maka semakin besar efektifitas penghambatan ekstrak terhadap pertumbuhan Plasmodium berghei

\section{HASIL}

\section{Hasil Uji Aktivitas Antimalaria Ekstrak Batang Talikuning}

Aktivitas antimalaria ekstrak batang talikuning ditetapkan melalui pengukuran derajat parasitemia. Derajat parasitemia diperiksa pada hari ke-0, 3, 5 dan 7 paska terapi. Pemeriksaan parasitemia hari ke-0 bertujuan untuk membuktikan bahwa semua mencit berada dalam range derajat parasitemia yang sama pada hari akan dilakukan pengobatan $(p>0,05)$. Hasil pemeriksaan derajat parasitemia disajikan pada Gambar 1.

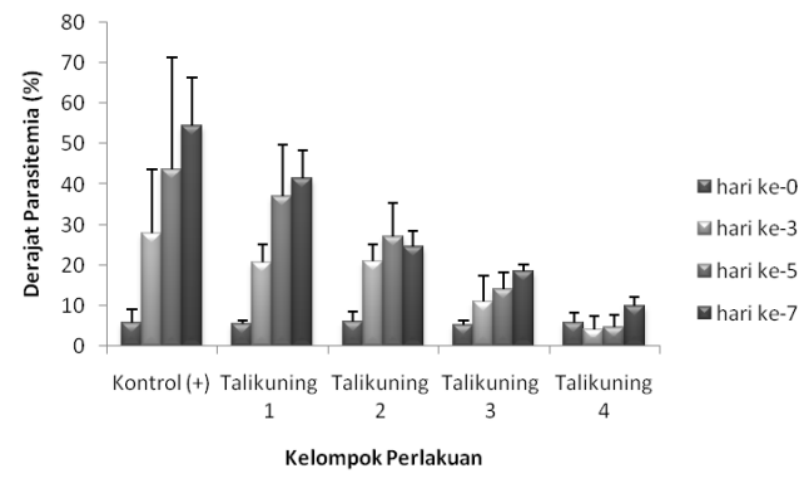

Gambar 1. Grafik derajat parasitemia kelompok perlakuan ekstrak batang talikuning terhadap kontrol

Keterangan:

Kontrol positif : Infeksi Plasmodium berghei tanpa terapi

Talikuning 1 : Pemberian terapi ekstrak batang talikuning dosis $0,001 \mathrm{mg} / \mathrm{gBB}$

Talikuning 2 :Pemberian terapi ekstrak batang talikuning dosis $0,01 \mathrm{mg} / \mathrm{g} B \mathrm{~B}$

Talikuning 3 : Pemberian terapi ekstrak batang talikuning dosis $0,1 \mathrm{mg} / \mathrm{g} \mathrm{BB}$

Talikuning 4 : Pemberian terapi ekstrak batang talikuning dosis 1 $\mathrm{mg} / \mathrm{gBB}$

Dari Gambar 1 dapat dilihat rata-rata derajat parasitemia 
untuk semua kelompok perlakuan terapi ekstrak batang talikuning (pada hari ke-3,5 dan 7) lebih rendah dibanding kelompok kontrol positif. Diketahui pula bahwa pada hari ke-5 dan ke7 pasca terapi seiring dengan peningkatan dosis terjadi penurunan rata-rata derajat parasitemia untuk semua perlakuan terapi talikuning mulai dari talikuning 1, talikuning 2, talikuning 3 dan talikuning 4 .

\section{Penentuan ED50}

Harga ED50 menunjukkan besarnya dosis bahan uji yang dapat menghambat $50 \%$ pertumbuhan Plasmodium ber

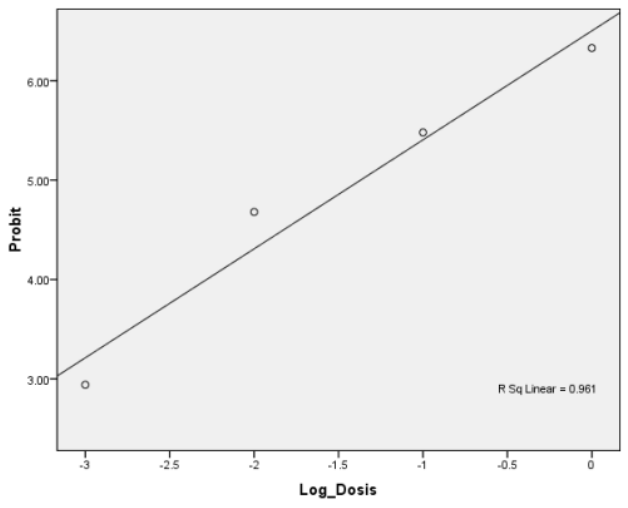

Gambar 2. Kurva hubungan probit persentase penghambatan pertumbuhan parasit dengan dosis dari ekstrak batang talikuning (Anamirta cocculus)

Dari hasil analisis data didapatkan harga ED50 dari ekstrak batang Talikuning sebesar 0,043 mg/g BB mencit setara dengan $4,7 \mathrm{mg} / \mathrm{kg} \mathrm{BB}$ manusia.

Hasil Uji Aktivitas Antimalaria Dosis Kombinasi Artemisin dan Ekstrak Batang Talikuning

\section{Derajat Parasitemia}

Pada penelitian ini dosis artemisin yang digunakan adalah $0,04 \mathrm{mg} / \mathrm{g}$ bb (6). Sedangkan dosis ekstrak batang talikuning yang digunakan adalah dosis $0,001 \mathrm{mg} / \mathrm{gbb}$; 0,01 mg/gbb; 0,1 mg/gbb dan $1 \mathrm{mg} / \mathrm{gbb}$ (10). Derajat parasitemia diperiksa pada hari ke-0, hari ke-3, hari ke-5 dan hari ke-7 (Gambar 3).

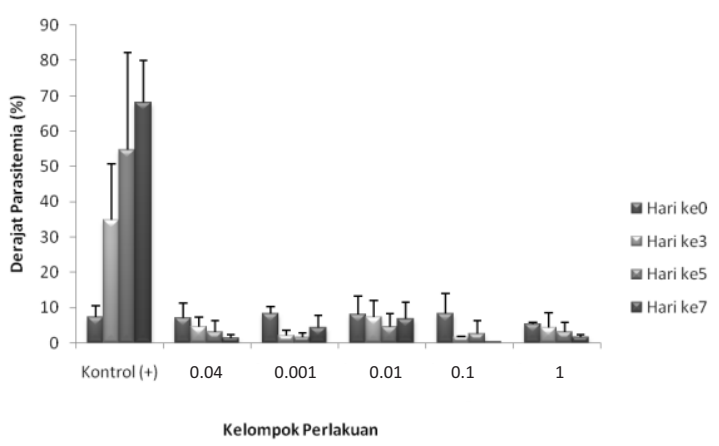

Gambar 3. Grafik derajat parasitemia terapi kombinasi artemisin-talikuning

\section{DISKUSI}

Penelitian ini bertujuan untuk mengetahui efek antimalaria ekstrak batang talikuning (Anamirta cocculus) dan kombinasinya dengan artemisin pada mencit yang diinfeksi Plasmodium berghei. Batang tanaman talikuning pada penelitian ini diambil dari daerah Papua yang telah di identifikasi oleh pusat penelitian Biologi-LIPI.

\section{Aktivitas Antimalaria Ekstrak Batang Talikuning (Anamirta} cocculus) Monoterapi

Pada Gambar 1 terlihat bahwa rata-rata derajat parasitemia hari ke-0 sebelum terapi adalah $5-7 \%$. Analisis statistik menunjukkan tidak adanya perbedaan derajat parasitemia antar kelompok perlakuan pada hari ke- 0 . Hal ini menunjukkan bahwa hari ke-0 semua mencit berada dalam derajat parasitemia yang sama. Pada kelompok kontrol positif terlihat terjadi peningkatan derajat parasitemia yang cukup tinggi seiring bertambahnya hari perlakuan yaitu pada hari ke-3 $(34,75 \%)$, hari ke-5 (54,8\%) dan hari ke-7 (68,20\%). Pada perlakuan talikuning dosis $0.001,0.01,0.1$ dan $1 \mathrm{mg} / \mathrm{g}$ BB juga menunjukkan adanya peningkatan derajat parasitemia seiring dengan bertambahnya hari perlakuan (Gambar 1). Pada perlakuan terapi talikuning tersebut peningkatan derajat parasitemia lebih rendah di bandingkan kontrol positif. Hasil analisis statistika menunjukkan adanya perbedan yang bermakna $(p<0,005)$ baik pada perlakuan talikuning dosis $0.001,0.01$, 0.1 dan $1 \mathrm{mg} / \mathrm{g}$ BB terhadap kontrol positif. Hal ini menunjukkan adanya peng-hambatan pertumbuhan Plasmodium berghei yang bermakna pada mencit yang diterapi ekstrak batang talikuning.

Penghambatan pertumbuhan Plasmodium berghei pada penelitian ini diyakini karena ekstrak kasar batang talikuning mengandung senyawa aktif yang dapat menghambat pertumbuhan parasit tersebut yaitu adanya kandungan senyawa alkaloid kuartener (berberine, palmatine, magnoflorine dan columbamine) (10).

Senyawa alkaloid kuartener (berberine, palmatine, magnoflorine dan columbamine) merupakan struktur senyawa yang mengandung nitrogen kuartener yang telah diketahui dapat menghambat pertumbuhan Plasmodium dengan cara mengeblok transport intraseluler kolin (13). Senyawa kolin diperlukan untuk biosintesis phospholipid dalam pembentukan membran parasit untuk menutup parasitophorous vacuole, sitosol dan berbagai subcellular compartement. Pengeblokan transport kolin ini telah digunakan sebagai salah satu strategi pengobatan malaria (3).

Senyawa berberine, palmatine, magnoflorine dan columbamine ini juga digolongkan ke dalam senyawa quinolin. Senyawa quinolin telah diketahui mampu membunuh parasit malaria dengan mekanisme kerja pada food vacuole parasit yaitu dengan mencegah pembentukan "heme polymerase" sehingga hemozoin tidak terbentuk (3).

Peningkatan konsentrasi/dosis pemberian pada penelitian ini berhubungan kuat dengan peningkatan efek (doseeffect relationship). Hal ini kemungkinan disebabkan karena peningkatan dosis pemberian diikuti dengan peningkatan absorpsi senyawa aktif dan peningkatan konsentrasi obat dalam plasma darah sehingga ikatan obat-reseptor meningkat yang berpengaruh langsung terhadap peningkatan efek penghambatan pertumbuhan parasit. 
Dalam penelitian ini telah didapatkan persentase penghambatan $50 \%$ pertumbuhan Plasmodium berghei ekstrak batang talikuning monoterapi terhadap kontrol (ED50) sebesar 0,043 mg/g BB mencit yang setara dengan $4,7 \mathrm{mg} / \mathrm{kg}$ BB manusia. Suatu senyawa antimalaria dikatakan mempunyai aktivitas yang sangat bagus dan prospektif sebagai bahan obat jika ED50 kurang dari 10 $\mathrm{mg} / \mathrm{g}$ BB manusia $(18,10)$. Hasil analisis derajat parasitemia pemberian ekstrak batang talikuning dosis 0,1 $\mathrm{mg} / \mathrm{g}$ bb dan $1 \mathrm{mg} / \mathrm{gbb}$ menunjukkan hasil yang tidak berbeda dengan pemberian artemisin monoterapi, baik pada hari ke-3, hari ke-5 dan hari ke-7 paska terapi.

Aktivitas Antimalaria Ekstrak Batang Talikuning (Anamirta cocculus) yang Dikombinasi dengan Artemisin

Tujuan pemberian obat dosis kombinasi pada penelitian ini adalah untuk mengetahui efek pemberian kombinasi talikuning-artemisin terhadap derajat parasitemia mencit yang telah diinfeksi Plasmodium berghei. Saat ini obat antimalaria yang direkomendasikan oleh WHO adalah Artemisin Combination Therapy (ACT), yaitu kombinasi dari arthemeter-lumefantrin, artemisin-naftaquin, artemisin-piperaquin, artesunat-antibiotika, artesunatpironaridin, dihidroartemisin-piperakuin (19). Namun telah ada laporan bahwa resistensi terhadap kombinasi artemether-lumefantrine sudah terjadi di Kamboja (20). dan di Indonesia khususnya di Papua telah dilaporkan adanya penurunan efikasi AAQ (artesunate-amodiakuine) (4).

Artemisin yang diberikan adalah artesunat. Sesudah pemberian per-oral artesunat dihidrolisis dengan cepat oleh asam lambung dan esterase di plasma dan eritrosit (21). Absorbsi artemisin yang diberikan per oral terjadi ketika konsentrasinya mencapai $30 \%$ atau kurang. Kadar puncak plasma terjadi beberapa menit sesudah pemberian (21).

Mekanisme kerja artemisin yang baru membuktikan bahwa artemisin bekerja melalui penghambatan enzim ATPase bergantung kalsium (PfATP6). Radikal bebas yang dihasilkan artemisin mengikat dan menghambat PfATP6 secara ireversibel dan spesifik (22). Fungsi ATPase pada

\section{DAFTAR KEPUSTAKAAN}

1. World Health Organization. World Malaria Report. (Online) 2008:144 http://www.malaria.org/ malaria2008.pdf [diakses pada 22 juli 2009].

2. Harijanto PN, Nugroho A, dan Gunawan AC. Malaria dari Molekuler ke Klinis. Edisi 2. Jakarta: EGC; 2010.

3. Rosenthal PJ. 2003. Review Antimalarial Drug Discovery: Old and New Approaches. The Journal of Experimental Biology. 2003; 206(21): 3735-3744.

4. Harijanto PN. Buku Ajar Ilmu Penyakit Dalam. Jakarta: PIP FKUI; 2006; 1732-1744.

5. Olliaro PL and Taylor WR. Developing Artemisinin sed Drug Combinations for The Treatment of Drug Resistant Falciparum Malaria. Journal of Postgraduate Medicine. 2004; 50: 40-44.

6. Sardjono TW dan Fitri LE. Malaria, Mekanisme Terjadinya Penyakit dan Pedoman Penanganannya. Malang: Lab Parasit FKUB; 2007

7. Noedl H, Se Y, Schaecher K, Smith B, Socheat D, and sistim kompleks pompa ion $\mathrm{Na}+/ \mathrm{K}+$ adalah mengatur kadar ion di dalam sel. Kegagalan fungsi PfATP6 mengakibatkan penurunan drastis ion kalium dalam sel yang sangat mematikan parasit (23). Pada penelitian ini dipakai sediaan dalam bentuk ekstrak kasar dari batang tanaman talikuning, hal ini memungkinkan masih terdapat aneka ragam kandungan senyawa kimia yang mempunyai sifat fisika kimia dan aktivitas biologis yang berbeda. Sifat kandungan senyawa aktif tersebut sangat berpengaruh terhadap efek antimalaria yang ditimbulkan.

Derajat parasitemia dosis kombinasi artemisin-talikuning (Gambar 3) pada hari ke-0 sebelum terapi adalah 5-8\%. Analisis statistik menunjukkan tidak adanya perbedaan derajat parasitemia antar kelompok perlakuan pada hari ke-0. Hal ini menunjukkan bahwa hari ke-0 semua mencit berada dalam range derajat parasitemia yang sama. Hasil uji statistik aktivitas antimalaria ekstrak batang talikuning (Anamirta cocculus) yang dikombinasikan dengan artemisin menunjukkan tidak ada perbedaan yang signifikan terhadap artemisin monoterapi $(P>0,05)$ baik pada hari ke-3, hari ke-5 dan hari ke-7 paska terapi. Hal ini menunjukkan bahwa ekstrak batang talikuning tidak meningkatkan atau menurunkan kerja artemisin secara bermakna.

Berdasarkan analisis data dan pembahasan terhadap hasil Uji aktivitas antimalaria ekstrak batang talikuning (Anamirta cocculus) dan kombinasinya dengan artemisin secara in vivo dapat disimpulkan sebagai berikut bahwa ekstrak batang talikuning (Anamirta cocculus) mampu menghambat pertumbuhan Plasmodium berghei pada mencit dengan nilai ED50 sebesar 0,043 mg/g BB mencit yang setara dengan $4,7 \mathrm{mg} / \mathrm{kg}$ BB manusia sedangkan pada pemberian kombinasi artemisin-talikuning tidak terbukti mempunyai efek yang lebih baik dari pada pemberian artemisin monoterapi secara bermakna.

\section{UCAPAN TERIMAKASIH}

Penulis mengucapkan terimakasih kepada Dr. Dorta Simamora, M.Si., atas sumbangan tanaman talikuning, dan terimakasih kepada Fakultas Kedokteran Universitas Brawijaya yang telah mendanai penelitian ini.

Fukuda M. Evidence of Artemisinin-Resistant Malaria in Western Cambodia. The New England Journal of Medicine. 2008: 359(24); 2619-2620.

8. Tjitra E. Pengobatan Malaria dengan Kombinasi Artemisin. Simposium Nasional Pengendalian Malaria. Surabaya, 29-30 November, 2004.

9. Leiden University Medical Center (LUMC). The Plasmodium berghei Research Model of Malaria. Chapter 2 Introduction to Plasmodium berghei. (Online) 2002. http://www.lumc.nl/1040/research/ malaria/model05.html

10. Herintsoa R, Baholy RR, Solofoniaina $A R$, et al. Screening of Plant Extract for Searching Antiplasmodial Activity. 11th NAPRECA Symposium Book of Proceedings. Madagascar, 2005.

11. Duke JA. Taxon: Anamirta cocculus (L.) Wight \& Arn. (Online) 2005. http://www.ars-grin.gov/cgibin/npgs/html/taxon.pl?3069 [diakses tanggal 6 Oktober 2009]. 
12. Verpoorte RJ, Siwon MEM, Tieken and Svendsen B. Studies on Indonesian Medicinal Plants. The Alkaloid of Anamirta cocculus. State University of Leiden, The Netherland. 1981.

13. Ancelin ML and Vial HJ. Quaternary Ammonium Coumpounds Efficiently Inhibit Plasmodium Falciparum Growth in Vitro by Impairment of Choline Transport. Antimicrobial Agent and Chemotherapy. 1986; 29(5): 814-820.

14. Phillipson JD and Wrigth CW. Antiprotozoal Agents from Plant Sourch. Planta Medica. 1991; 57 (7): p. 5359.

15. Blazquez S,Thiberge S, Amino R, and Ménard R. 2008. In Vivo Imaging of Pre-erythrocytic Forms of Murine Plasmodium Parasites. In: Kirsten M, Ljungstrom I, Petmann $H$, Scherf $A$, and Wahlgren $M$ (Ed). Methods in Malaria Research $5^{\text {th }}$ edition. Paris: BioMalPar; hal. 148-152.

16. Palasuwan $A$, Soogarun $S$, Lertlum $T$, Pradiwat $P$, and Wiwanitkit V. Inhibition of Heinz Body induction in an In Vitro Model and Total Antioxidant Activity of Medicinal Thai Plant. Asian Pasific Journal of Cancer Prevention. 2005; 6(4): 458-463.

17. Rojsanga P, Gritsanapan W, and Sontornsuk L. Determination of Berberine Content in The Stem Extracts of Coscinium Fenestratum by TLC Densitometry. Medical Principles and Practice. 2006; 15(5): 373-378.

18. Tushar KV, George S, Remashree, and Balachandran I. Coscinium Fenestratum, Critical Endangered and Highly Trated Medicinal Species. Journal of Plant Sciences. 2008; 3(2): 133-145.

19. Kusumawardhani D,Widyawaruyanti, dan Kusumawati. Uji Antimalaria In Vivo Ekstrak
Sambiloto Terstandar (Parameter kadar androgofolida) pada Mencit. Lembaga Penelitian Universitas Airlangga. 2005.

20. World Health Organization. Global Malaria Control and Elimination. Report of a Meeting on Containment of Artemisinin Tolerance. Geneva, 2008.

21. Denis MB, Tsuyuoka R, Lim P, et al. Efficacy of Artemether-lumefantrine for The Treatment of Uncomplicated Falciparum Malaria in Northwest Cambodia. Tropical Medicine \& International Health. 2006; 11(12): pp. 1800-1807.

22. Cook GC and Zumla A. Manson's Tropical Disease. 21th edition. London: Saunder Elseiver Science; 2003.

23. Ridley RG. Malaria: To Kill a Parasit. Nature. 2003; 424(6951): 887-889

24. Nurachman Z. Artemisin, Pembunuh Parasit Malaria. ( $\mathrm{O} n \mathrm{I}$ i n e ) 2005 . http:lunisosdem.oru/kliping detail.php?aid2652\&ca

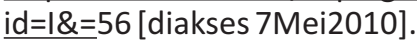

25. Ditjen POM. Farmakope Indonesia. Edisi 3. Jakarta: Departemen Kesehatan RI; 1979; hal. 9.

26. Wiser MF. Mechanism of Drug Action and Resistance. ( O n I i n e ) 2003. http://www.tulane.edu/ wiser/protozoology/notes/d rugs.html\#resist

27. Sardjono TW. Obat Antimalaria. Universitas Brawijaya, Malang. 2007.

28. Olliaro PL and Taylor WR. Developing Artemisinin Based Drug Combinations for The Treatment of Drug Resistant Falciparum Malaria: A Review. Journal of Postgraduate Medicine. 2004; 50(1):40-44. 